\title{
Evaluation of Factors Influencing Job Satisfaction
}

\author{
Barbara A. Sypniewska ${ }^{1}$
}

ABSTRACT

\begin{abstract}
The term "job satisfaction" is derived from the humanities, psychology and sociology. In the field of psychology, it is a state where an employee has an emotional perception of his situation and reacts with feelings of pleasure or pain. In sociology, it is considered a variable in different categories related to how each employee evaluates and thinks about his work. Job satisfaction is closely related to the performance and quality of work performed by an employee and, consequently, translates into the success of an organization, because a satisfied employee builds and participates in the success of any organization. This article presents the results of the research conducted by the author in 2012 on a sample of 215 people. Respondents represented different organizations. The aim of the study was to identify and assess the significance of individual factors influencing satisfaction and dissatisfaction with work and demonstrate their impact on the overall assessment of job satisfaction. The study showed that between the weight attributed to individual factors and overall job satisfaction there are many statistically significant correlations referring mainly to selected on the basis of analysis respondents' groups. The study confirms the raised thesis concerning the validity of research in the factors affecting the general feeling of satisfaction by the employees.
\end{abstract}

KEY WORDS: $\quad$ job satisfaction; job contentment

JEL Classification: M54

' Wyższa Szkoła Finansów i Zarządzania w Warszawie, Poland

\section{Introduction}

The concept of satisfaction originated from the humanistic school of thought, one of the branches of psychology. The precursor and a supporter of the school was A. Maslow, who believed that people seek to satisfy their needs in a proper hierarchical order. From the lowest level and moving upward, he ranks first physiological needs, then safety, belonging, appreciation and self-realization. According to Maslow, only after feeling satisfaction in meeting the needs of a lower level

Correspondence concerning this article should be addressed to: Barbara A. Sypniewska, Wyższa Szkoła Finansów i Zarządzania W Warszawie, 55 Pawia Str. , Warsaw 01-030, Poland. E-mail: agata.sypni@op.pl is there a desire to implement a need on a higher level (Hoffman, 2003, p. 156).

In the literature of subject, satisfaction is identified as an employee's positive attitude towards the company, co-workers and, finally, the job. The concept of satisfaction refers to the sphere of expectations in relation to the company and is, therefore, a purely subjective notion, but translates into quality of work (Mrzygłód, 2004, pp. 183-196).

The term "job satisfaction" is commonly used in everyday language and many authors interchangeably use the term "job satisfaction" with "job contentment".

In the psychological literature we can find the statement that "contentment is the emotional reaction of pleasure or pain, experienced in connection 
with performing specific tasks, functions and roles" (Bańka, 2002, pp. 321-350). Job contentment may thus be regarded as the emotional reaction to the situation at work (Ariani, 2012, pp. 46-56). In sociology, we consider this variable in categories related to how each employee assesses his work and what he thinks about it. These categories are dealt with in the same way regardless of whether we are operating with the term "job satisfaction" or "job contentment". Generally, the definition of job satisfaction includes factors that can be grouped into four areas: economic aspects of work, interpersonal relationships, activities and tasks, and working conditions (Herzberg, 1965, pp. 364-376, Locke et al., 1964, pp. 313-319; Zalewska, 2001, pp. 197-218).

Economic aspects of work apply to all quantifiable and financial aspects the employee may obtain for his work but also includes penalties and the possibility of development and advancement. These aspects are part of the motivation system of the organization.

Interpersonal relationships at the workplace are extremely important for employees. This thesis is confirmed by numerous studies concerning satisfaction and job contentment. In this article we will also attempt to prove the above thesis. Interpersonal relationships are mainly about an employee's quality of relationships with supervisors and other employees, his workplace's general atmosphere, his means of communication, whether he can give and receive feedback and recognition from his superiors.

Activities and tasks can be evaluated on a scale that ranges from monotonous and repetitive to varied and interesting. However, the assessment of activities and tasks is a subjective process that is affected by various factors because the employee has to evaluate the excessiveness or deficiency of his tasks, his time pressure, the level of independence and responsibility for the results of his work that he bears, his independence in decision making as well as the content of his work.

Working conditions concern aspects of the work environment that should contribute to the conduciveness and safety felt by employees at the workplace. They include, among others, workplace equipment, tools, computers, cars, telephones and the aspects that are regulated by health and safety regulations.

All of these factors are assessed by an employee in terms of his satisfaction or dissatisfaction. They are partial factors in the organization of motivation systems. Thus, the overall job contentment and job satisfaction of an employee consists of the evaluation of all the individual factors of incentive schemes.

One of the dominant theories of motivation is the two-factor theory by Frederick Herzberg (Zalewska, 2003). Thanks to ongoing research, he demonstrated the existence of two groups of factors that influence satisfaction or dissatisfaction with work. The first group was called the external factors (hygiene factors) and includes supervisors, working conditions, wages and safety. The other group of factors was named the internal factors (motivators). They are so-called higher needs: recognition by others, work performance, accountability and development. According to Herzberg, while the positive assessment of the first group of factors does not increase job satisfaction, and the lack of them is felt demotivating. The other group of factors contribute to the increase in job satisfaction (Armstrong, 2000; Griffin, 1998; Stride, Wall \& Catley, 2007). Herzberg examined the components of job satisfaction and concluded that the use of different programs enriches the content of work, thus making work more attractive and increasing job satisfaction. Proponents of this method claim that they can eliminate the boredom and monotony of work, but there is no certainty that in this way will job contentment increase. The evidence which confirmed that it was the research conducted by, among others, Feina (1970).

Subsequent studies have verified the theory adopted by Herzberg. It turns out that the weightage of attributed factors influencing job contentment changes depending on the job or position held. For example, blue-collar workers appreciate more hygiene factors than motivators as hygiene factors shape their sense of job satisfaction more than motivators do. In contrast, white-collar workers cite motivators as sources of job satisfaction (Harris \& Locke, 1974, pp. 369-370).

M. Armstrong mentions, among the basic conditions for feeling job satisfaction, the following elements: a relatively high salary, opportunity for promotion, supervisors, equitable wage system, the integration of co-workers and tasks (Armstrong, 2005, p 220). However, because these individual expectations and needs that Armstrong mentions combined with the ability to satisfy them at work determine the degree 
of satisfaction that is perceived, the feeling of satisfaction is, as was already stated, marked by subjectivism.

A. Pocztowski believes that the level of job satisfaction experienced by an employee is dependent on the amount of wages, advancement opportunities, management style, content of work, interpersonal relations, working conditions, work organization, management and corporate reputation (Pocztowski, 2003, p 450). In turn, P. Makin, G. Cooper and Ch. Cox (2000, pp. 82-83) claim that job satisfaction is an emotional mental state in the perception of positive and pleasant which proceeds with the evaluation of their own work or experience. They mention, among others, factors that influence the feeling of job satisfaction as: interesting work, well-paid jobs, the possibility of advancement, good superiors and good relationships with co-workers.

It should be emphasized that the significant influence on the level of satisfaction is, undoubtedly, a sense of justice. Justice is felt by workers in some degree for all of the factors that make up job contentment. The employee evaluates justice or rightness bonuses and if the result is positive, achieves satisfaction. According to the theory of justice, motivation in employees is the result of the satisfaction with what workers receives in exchange for their contributions. If they are treated fair, their motivation increases; if not, their motivation decreases.

According to M. Armstrong, job satisfaction can be developed by focusing on the internal factors of motivation: responsibility, achievement and recognition. The objective of managers should therefore be figuring out the different ways of delegating responsibility to give their employees the space and freedom to use their skills and abilities (Armstrong, 2004, p 132).

Job satisfaction can be seen as a multidimensional attitude. It consists, according to J. Mrzygłód, of the attitude of the employee to salary, promotion, coworkers, supervisor or work itself (Mrzygłód, 2004, pp. 183-196).

The employee satisfaction survey is an element that supports the development and correction of the motivation systems in an organization (Bojewska, 2006, pp. 481-495).

Contemporary studies on measuring the level of job satisfaction are based on the analysis of the previously mentioned four areas: economic aspects of work, interpersonal relationships, activities and tasks, and working conditions (Herzberg, 1965, pp. 134-143; Zalewska, 2001, pp. 197-218). There are various studies concerning the analysis of factors influencing job satisfaction. These studies began to attach importance to the inner traits of personality or cognitive judgments as factors responsible for the occurrence or nonoccurrence of job satisfaction (Furnham, 2008; Zalewska, 2003). There are also studies on internal and external factors affecting employee and job satisfaction. One of the internal factors taken into account is emotional intelligence (Jorfi, Fauzy Bin Yacco \& Md Shah, 2012, pp. 590-597). Job satisfaction is influenced by groups of factors associated with broadly understood internal work environments and worker characteristics. Subject and situational factors should therefore be considered together as factors that determine the perceived level of job satisfaction.

There are studies stressing the importance of relationships and the relations of the type of occupation (Argyle, 2004). There is repeated emphasis on the importance of the subjective perception of the work performed for the organization (Pratt \& Ashforth, 2003, pp.. 309-327).

Also important is the aspect binding job satisfaction, productivity and quality of work. There are two areas where a high level of job satisfaction significantly improves the quality of work. Positive emotions (in the case of satisfied employees) foster creative thinking (Brief \& Weiss, 2002, pp. 279-307). Undecided people may take excessive risks and act risky (Isen, 2005, pp. 527-549).

In addition, important aspects influencing job satisfaction are contacts, meetings and relationships with co-workers or superiors (Rogelberg et al., 2010, pp. 149-172).

What could be the benefits of having happy and satisfied employees? Generally, satisfied people build positive relationships based on cooperation and effective teamwork with others, thus increasing communication and ensuring proper communication and effective conflict mitigation (Isen, 2005, pp. 527-549). Satisfied employees mean reduced absenteeism, a high level of commitment to work, loyalty and permanence of employment, improved health and a lack of the desire to avoid work, simulated malaise and excuses to be absence from work. (Argyle, 2004). A high level of job 
Table 1. Distribution of frequency - the age the respondents

\begin{tabular}{|c|c|c|c|c|c|c|}
\hline \multirow[b]{3}{*}{ The age of the respondents } & \multicolumn{6}{|c|}{ Sex } \\
\hline & \multicolumn{2}{|c|}{ women } & \multicolumn{2}{|c|}{ men } & \multicolumn{2}{|c|}{ total } \\
\hline & $\mathbf{n}$ & $\%$ & $\mathbf{n}$ & $\%$ & $\mathbf{n}$ & $\%$ \\
\hline 20-29 years old & 116 & 75.8 & 46 & 74.2 & 162 & 75.3 \\
\hline 30-39 years old & 23 & 15.0 & 8 & 12.9 & 31 & 14.4 \\
\hline 40-49 years old & 9 & 5.9 & 5 & 8.1 & 14 & 6.5 \\
\hline 50-60 years old & 5 & 3.3 & 3 & 4.8 & 8 & 3.7 \\
\hline total & 153 & 100 & 62 & 100 & 215 & 100 \\
\hline
\end{tabular}

Notes: $\mathrm{n}$ - number of persons; \% - the percentage of the group

Table 2. The frequency distribution - position held by the respondents

\begin{tabular}{lcc}
\hline Position & $\mathbf{n}$ & \% \\
\hline managerial & 27 & 12.6 \\
professional & 67 & 31.2 \\
manual worker & 34 & 15.8 \\
administrative worker & 63 & 29.3 \\
other & 22 & 10.2 \\
no data & 2 & 0.9 \\
total & 215 & 100 \\
\hline
\end{tabular}

Notes: $\mathrm{n}$ - number of persons; $\%$ - percentage of the sample size

Table 3. Distribution of frequency - the period of employment in the company

\begin{tabular}{lcc}
\hline The period of employment in the company & $\mathbf{n}$ & $\%$ \\
\hline less than a year & 57 & 26.5 \\
1-2 years & 70 & 32.6 \\
3-5 years & 50 & 23.3 \\
5-10 years & 17 & 7.9 \\
Over 10 years & 20 & 9.3 \\
no data & 1 & 0.5 \\
In total & 215 & 100 \\
\hline
\end{tabular}

Notes: $\mathrm{n}$ - number of persons; $\%$ - percentage of the sample size

satisfaction increases an employee's commitment to work and frees him from stress and burnout (Maslach, 2000, pp. 13-31; Ogińska-Bulik, 2006; Sarmiento, Laschinger \& Iwasiw, 2004, pp. 134-143; Sęk, 2000, pp. 149-167), while the lack of job satisfaction results in increased absenteeism (Jachnis, 2008). A satisfied employee is more loyal, because he sees more benefits in staying with an organization than with leaving it (Jachnis, 2008). A disgruntled employee often thinks about changing his job; however, if he decides to stay, his motivation is low and causes performance degradation not only in his own work but also in the overall performance of the organization (Wang, Yang \& Wang, 2012, pp. 557-573). 
Table 4. Distribution of frequency - a form of employment in the company

\begin{tabular}{lcc}
\hline A form of employment in the company & $\mathbf{n}$ & $\%$ \\
\hline contract of indefinite duration & 103 & 47.9 \\
contract of employment for a specified amount of time & 57 & 26.5 \\
contract of mandate & 37 & 17.2 \\
contract for specific work & 4 & 1.9 \\
another form & 12 & 5.6 \\
no data & 2 & 0.9 \\
total & 215 & 100 \\
\hline
\end{tabular}

Notes: $\mathrm{n}$ - number of persons; $\%$ - percentage of the sample size

The objective of many studies is to identify the initial level of satisfaction, identify the determinants of satisfaction and define a company's activities which undoubtedly result in increasing the sense and feeling of satisfaction and job contentment of its employees.

\section{Methodology of research}

The study was conducted during the months of June and July 2012. The study involved 215 respondents (153 women and $62 \mathrm{men}$ ) who were matched in a random manner. The study was conducted specifically for the purpose of assessing the factors that affect job satisfaction and a questionnaire was designed to achieve this goal.

The aim of the study was to first identify and assess the significance of individual factors that influence satisfaction and dissatisfaction with work and then demonstrate their impact on the overall assessment of job satisfaction.

The following basic hypothesis has been drawn out:

The individual factors in job satisfaction have an effect on the perception of an employee's overall job contentment.

In addition, a number of detailed hypotheses have been drawn out:

An overall assessment of the job satisfaction of employees consists of the evaluation of individual factors comprising it.

The individual components of job satisfaction are assessed differently by employees depending on their age, gender, length of service, position held and form of employment.

The research issues are as follows:

What factors influence the job satisfaction of employees?
Do the individual component factors of job satisfaction affect different groups of workers in the same way?

How are the individual factors which contribute to job satisfaction evaluated by employees who differ in terms of age, sex, length of service, form of employment and position held?

\section{The results of research}

This section presents the results of the analyses that were conducted to verify this study's hypotheses. This study involved 215 respondents. The majority of the respondents (over 75\%) are aged 20-29 and in this age group, 116 of the respondents were women and 46 were men. Significantly fewer people, the remaining $25 \%$ of respondents, were in the group aged 30-60. Among the 215 respondents, women numbered 153 while there were 62 men. Table 1 shows frequency distribution for the age of the respondents.

The respondents were asked about the positions they held. They could choose between 4 options: managerial position, professional, manual worker and administrative worker. Most of the respondents were people who worked as specialists (67 people) and administrative workers (63 people). Manual workers numbered 34 and 27 respondents held managerial positions. Two people did not respond to this question, while only 22 respondents indicated that they held positions other than those mentioned earlier but without specifying what positions they held. Table 2 shows the frequency distribution for the positions held by the respondents.

Most of the respondents have worked in their companies for at most two years. 57 people have worked for less than a year at the company and for a period of 
Table 5. Descriptive statistics for the factors affecting job contentment

\begin{tabular}{|c|c|c|c|c|}
\hline Factor & M & SD & $\min$ & $\max$ \\
\hline Stability of employment & 3.34 & 0.75 & 1 & 4 \\
\hline Communication with management & 3.09 & 0.74 & 1 & 4 \\
\hline Communication between employees and other groups & 3.06 & 0.78 & 1 & 4 \\
\hline possibility of promotion & 3.03 & 0.84 & 1 & 4 \\
\hline Possibility of development & 2.98 & 0.83 & 1 & 4 \\
\hline Content of work & 2.92 & 0.78 & 1 & 4 \\
\hline Recognition of superiors & 3.08 & 0.78 & 1 & 4 \\
\hline Good relationship with superiors & 3.13 & 0.73 & 1 & 4 \\
\hline Independence in decision-making & 3.00 & 0.79 & 1 & 4 \\
\hline Company culture & 2.90 & 0.81 & 1 & 4 \\
\hline Safety at work & 3.00 & 0.74 & 1 & 4 \\
\hline Good relationships with coworkers & 3.34 & 0.62 & 1 & 4 \\
\hline Atmosphere at work & 3.39 & 0.67 & 1 & 4 \\
\hline
\end{tabular}

Notes: $\mathrm{M}$ - the average rank, SD - standard deviation, min - minimum value, max - the maximum value

1 to 2 years, there were 70 people. Meanwhile, the least number of people (17) have worked at the company for a 5 to 10 years period and there were 20 respondents who have worked at the company for more than 10 years. Table 3 shows the frequency distribution for the period of employment of the respondents in the company to which answers to questions in the survey were addressed.

Most of the respondents worked under a contract of indefinite duration - 103 people, representing $47.9 \%$ of all respondents, while 57 (26.5\%) respondents were hired for a specified amount of time. 41 people (19\% of all respondents) worked on the basis of either a mandatory contract or contract work. Table 4 shows the frequency distribution for the form of employment of the respondents in the company to which the answers were given.

\section{Factors that influence job satisfaction.}

The respondents were asked about the factors that influence job satisfaction. The subjects had to select which of the 13 factors influence their "great satisfaction", "satisfaction", "low satisfaction" or are "irrelevant". Table 5 shows factors that, according to the respondents, had an impact on their job contentment, along with descriptive statistics to estimate the significance of these factors.
For the respondents, the most important factor influencing job satisfaction was the atmosphere at work, while the least important factor was the culture of the company.

Figure 1 shows the above factors sorted from most to least important.

For the respondents the two equally most important factors influencing job satisfaction, after the atmosphere at work, are: stability of employment and good relations with co-workers. Good relations with superiors and communication with management are the fourth and fifth most important factors. Content of work and the possibility of development are the second and third least important factors for respondents.

\section{Cluster analysis}

In order to look accurately at the individual factors influencing job contentment, ratings ofthese factors were subjected to cluster analysis usingthe k-average method. Table 6 shows standardized rating values in separate clusters, together with the test of statistical significance of differences.

Significant differences were noticed between groups in all analyzed factors.

There are four distinct clusters. The final cluster centers are presented in Figure 2. 


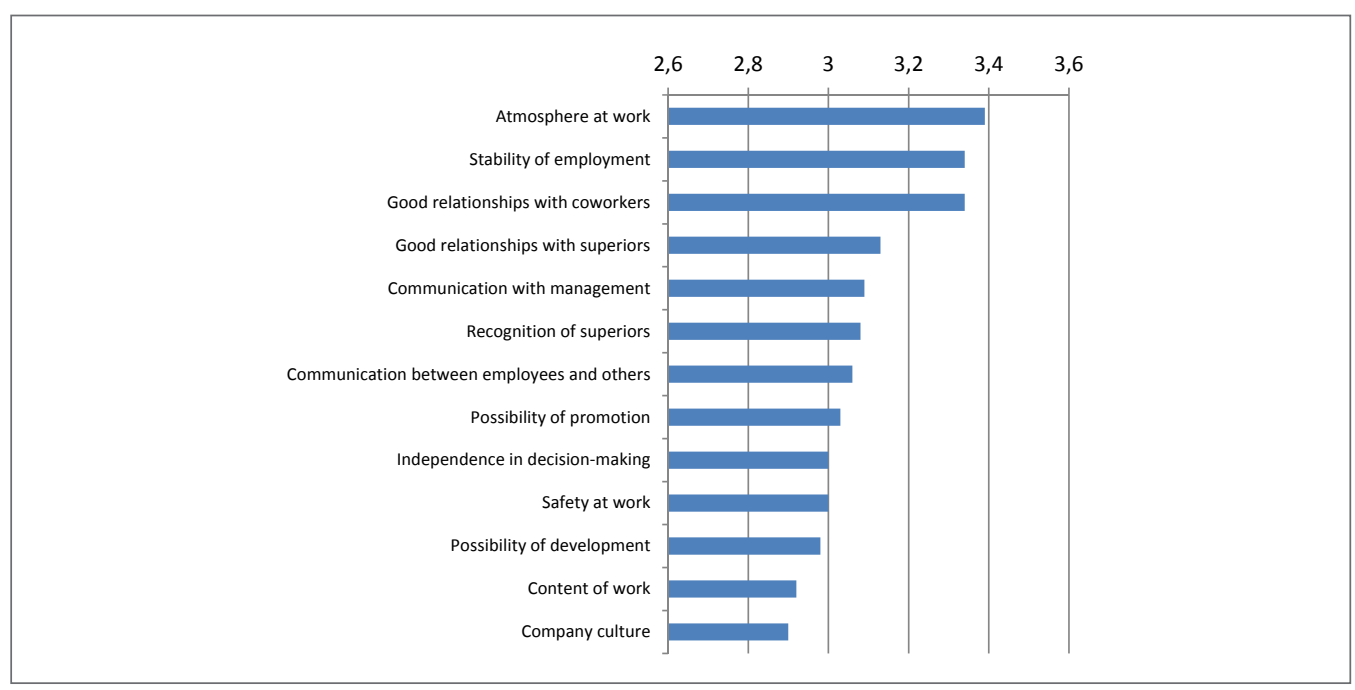

Figure 1. Average values of the importance of factors influencing job contentment

Table 6. Final cluster centers along with the test of statistical significance

\begin{tabular}{|c|c|c|c|c|c|c|c|c|}
\hline \multicolumn{9}{|c|}{ Cluster } \\
\hline & & No. 1 & No. 2 & No. 3 & No. 4 & & & \\
\hline variable & & $\mathrm{n}=18$ & $\mathrm{n}=45$ & $n=72$ & $n=59$ & $\mathrm{~F}$ & $d f$ & $\mathrm{p}$ \\
\hline Stability & M & -0.67 & -0.39 & 0.12 & 0.41 & \multirow{2}{*}{$10.08^{* * *}$} & \multirow{2}{*}{3.190} & \multirow{2}{*}{0.001} \\
\hline of employment & SD & 1.53 & 1.06 & 0.77 & 0.73 & & & \\
\hline Communication & M & -1.32 & -0.24 & 0.67 & -0.12 & \multirow{2}{*}{$40.70^{* * *}$} & \multirow{2}{*}{3.190} & \multirow{2}{*}{0.001} \\
\hline with management & SD & 0.92 & 0.75 & 0.67 & 0.75 & & & \\
\hline Communication between & M & -1.35 & 0.13 & 0.60 & -0.29 & \multirow{2}{*}{$35.52^{* * *}$} & \multirow{2}{*}{3.190} & \multirow{2}{*}{0.001} \\
\hline employees and others & SD & 0.88 & 0.82 & 0.68 & 0.83 & & & \\
\hline Possibility & M & -0.90 & -0.62 & 0.46 & 0.36 & \multirow{2}{*}{$27.67^{* * *}$} & \multirow{2}{*}{3.190} & \multirow{2}{*}{0.001} \\
\hline of promotion & SD & 0.89 & 0.90 & 0.79 & 0.72 & & & \\
\hline Possibility & M & -0.85 & -0.54 & 0.33 & 0.29 & \multirow{2}{*}{$16.07^{* * *}$} & \multirow{2}{*}{3.190} & \multirow{2}{*}{0.001} \\
\hline of development & SD & 0.91 & 1.05 & 0.86 & 0.81 & & & \\
\hline Content & M & -1.04 & -0.53 & 0.19 & 0.49 & \multirow{2}{*}{$21.79 * * *$} & \multirow{2}{*}{3.190} & \multirow{2}{*}{0.001} \\
\hline of work & SD & 0.87 & 0.93 & 0.95 & 0.68 & & & \\
\hline Recognition & M & -0.74 & -0.82 & 0.56 & 0.25 & \multirow{2}{*}{$33.56^{* * *}$} & \multirow{2}{*}{3.190} & \multirow{2}{*}{0.001} \\
\hline of superiors & SD & 1.01 & 0.94 & 0.69 & 0.79 & & & \\
\hline Good relationship & M & -0.85 & -0.66 & 0.62 & 0.13 & \multirow{2}{*}{$31.37^{* * *}$} & \multirow{2}{*}{3.190} & \multirow{2}{*}{0.001} \\
\hline with superiors & SD & 1.07 & 0.88 & 0.68 & 0.80 & & & \\
\hline Independence & M & -0.78 & -0.23 & 0.26 & 0.16 & \multirow{2}{*}{$7.22^{* * *}$} & \multirow{2}{*}{3.190} & \multirow{2}{*}{0.001} \\
\hline in decision-making & SD & 0.88 & 1.15 & 0.84 & 0.92 & & & \\
\hline Company & $M$ & -1.32 & -0.54 & 0.44 & 0.22 & \multirow{2}{*}{$28.39 * * *$} & \multirow{2}{*}{3.190} & 1 \\
\hline culture & SD & 0.87 & 0.97 & 0.83 & 0.77 & & & 0.001 \\
\hline Safety & M & -1.05 & -0.72 & 0.58 & 0.11 & & 3190 & \\
\hline at work & SD & 0.99 & 0.89 & 0.71 & 0.84 & $33.01 \times n$ & 3.190 & 0.001 \\
\hline Good relationship & M & -1.53 & -0.09 & 0.81 & -0.47 & $7073^{* * * *}$ & 3190 & 0001 \\
\hline with coworkers & SD & 1.12 & 0.73 & 0.58 & 0.63 & & & \\
\hline Atmosphere & M & -1.90 & -0.28 & 0.79 & -0.10 & $5 * * *$ & 3190 & (001 \\
\hline at work & SD & 0,70 & 0,75 & 0,42 & 0,76 & 91.85 . & 3.190 & 0.001 \\
\hline
\end{tabular}

Notes: $\mathrm{M}$ - average value,SD - standard deviation, $\mathrm{F}$ - test statistic, df - degrees of freedom, $\mathrm{p}$ - statistical significance 


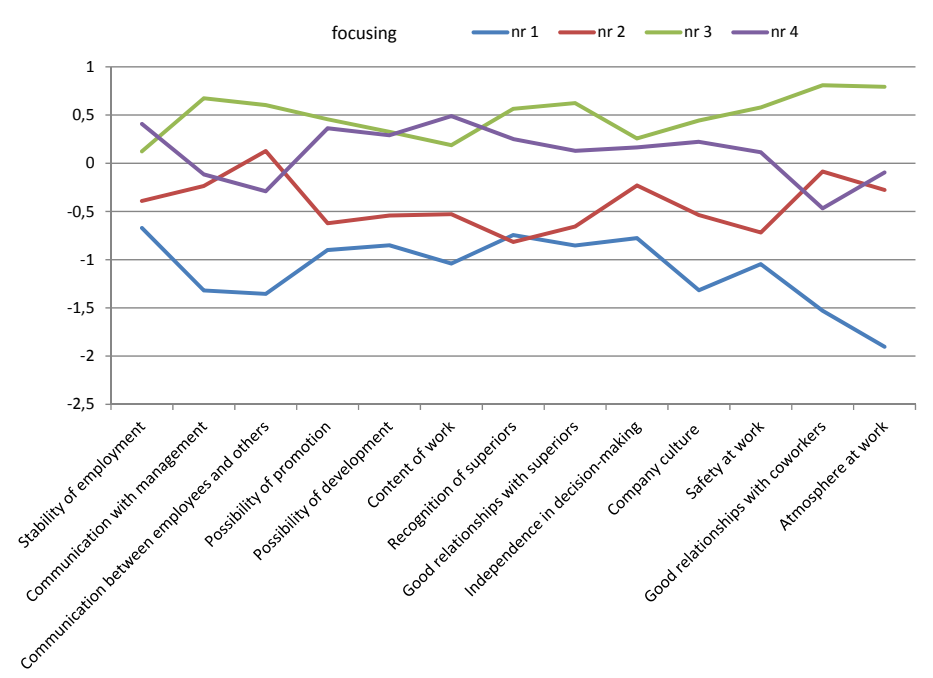

Figure 2. The final cluster centers

In the first cluster / group $(\mathrm{n}=18)$, respondents evaluated individual factors as have little effect on their job contentment.

The second cluster / group of the respondents (n $=45$ ) comprised of people who assessed that most of the factors, with the exceptions of communication between the employees and other groups, good relationships with colleagues and working atmosphere, have little impact on their job contentment.

The third cluster / group of the respondents $(n=$ 70) were formed by people who showed that all of the analyzed factors had a strong influence on their level of job contentment. The most important factors were communication with management, the recognition of superiors, good relations with superiors, good relationships with colleagues and working atmosphere.

The fourth cluster/group of the respondents $(n=$ 59) were people who evaluated that the most important factors for job contentment were job stability, opportunity for promotion, development opportunities and work content.

In addition, each cluster group was analyzed in terms of gender, age, position held, period of employment and form of employment. This procedure was intended to describe the characteristics of the respondents in the individual clusters, i.e., the description of:

- sex, age, period of employment in the company,

- held positions: managerial, professional, physical or administrative, and

- on what basis they are employed in a company: agreement on fixed-term or indefinite contract or work order.

Based on test 2, there was a statistically significant correlation between belonging to one of four separate clusters and the sex of the respondents, $2(3)=16.58$, p $<0.01$. Table 7 presents the frequency distribution for the sex of the respondents from each cluster. $\chi \chi$

Among the respondents from cluster No. 1, No. 3 and No. 4, there were more women than men. In the group of people from cluster No. 2, the number of women and men were similar.

There was also a statistically significant relationship between belonging to one of four separate clusters and the age of the respondents, $2(9)=25.81$, p $<0.01$. Table 8 shows the frequency distribution for the age of the respondents from each cluster. $\chi$

Among those tested, in all four clusters most respondents were aged 20-29 with cluster No. 1 having the smallest percentage (50\%) of respondents in this age group. 
Table 7. Characteristics of separate clusters - sex of the respondents

\begin{tabular}{lccccccccc}
\hline \multicolumn{10}{c}{ Cluster } \\
\hline Sex & No. 1 & \multicolumn{1}{c}{ No. 2 } & & No. 3 & & No. 4 \\
women & $\mathrm{n}$ & $\%$ & $\mathrm{n}$ & $\%$ & $\mathrm{n}$ & $\%$ & $\mathrm{n}$ & $\%$ \\
men & 12 & 66.7 & 22 & 48.9 & 60 & 83.3 & 44 & 74.6 \\
In total & 6 & 33.3 & 23 & 51.1 & 12 & 16.7 & 15 & 25.4 \\
\hline
\end{tabular}

Notes: $\mathrm{n}$ - Number of persons; $\%$ - the percentage of the group

Table 8. Characteristics of separate clusters - the age of the respondents

\begin{tabular}{|c|c|c|c|c|c|c|c|c|}
\hline \multirow[b]{3}{*}{ Age } & \multicolumn{8}{|c|}{ Cluster } \\
\hline & \multicolumn{2}{|c|}{ No. 1} & \multicolumn{2}{|c|}{ No. 2} & \multicolumn{2}{|c|}{ No. 3} & \multicolumn{2}{|c|}{ No. 4} \\
\hline & $\mathrm{n}$ & $\%$ & $n$ & $\%$ & $n$ & $\%$ & $\mathrm{n}$ & $\%$ \\
\hline 20-29 years old & 9 & 50.0 & 36 & 80.0 & 64 & 88.9 & 44 & 74.6 \\
\hline $30-39$ years old & 3 & 16.7 & 6 & 13.3 & 7 & 9.7 & 11 & 18.6 \\
\hline $40-49$ years old & 4 & 22.2 & 2 & 4.4 & 1 & 1.4 & 3 & 5.1 \\
\hline $50-60$ years old & 2 & 11.1 & 1 & 2.2 & 0 & 0.0 & 1 & 1.7 \\
\hline In total & 18 & 100.0 & 45 & 100.0 & 72 & 100.0 & 59 & 100.0 \\
\hline
\end{tabular}

Notes: $\mathrm{n}$ - number of persons; $\%$ - the percentage of the group

Table 9. Characteristics of separate clusters - position

\begin{tabular}{lcccccccc}
\hline & \multicolumn{1}{c}{ Cluster } \\
\hline & \multicolumn{1}{c}{ No. 1 } & \multicolumn{1}{c}{ No. 2 } & \multicolumn{1}{c}{ No. 3 } & \multicolumn{2}{c}{ No. 4 } \\
\hline Position & $\mathrm{n}$ & $\%$ & $\mathrm{n}$ & $\%$ & $\mathrm{n}$ & $\%$ & $\mathrm{n}$ & $\%$ \\
managerial & 1 & 5.9 & 5 & 12.8 & 12 & 19.0 & 9 & 16.1 \\
professional & 2 & 11.8 & 12 & 30.8 & 23 & 36.5 & 25 & 44.6 \\
manual worker & 8 & 47.1 & 11 & 28.2 & 5 & 7.9 & 6 & 10.7 \\
administrative worker & 6 & 35.3 & 11 & 28.2 & 23 & 36.5 & 16 & 28.6 \\
In total & $\mathbf{1 7}$ & $\mathbf{1 0 0 . 0}$ & $\mathbf{3 9}$ & $\mathbf{1 0 0 . 0}$ & $\mathbf{6 3}$ & $\mathbf{1 0 0 . 0}$ & $\mathbf{5 6}$ & $\mathbf{1 0 0 . 0}$ \\
\hline
\end{tabular}

Notes: $\mathrm{n}$ - number of persons; $\%$ - the percentage of the group

A significant relationship was observed between belonging to one of four separate clusters and work position, 2 (9) $=22.98, \mathrm{p}<0.01$. Table 9 presents the frequency distribution of the respondents to their positions according to their particular clusters. $\chi$

Among the people from cluster No. 1, most were manual workers. In the group of people from the cluster No. 2, there were approximately the same amount of blue-collar workers, administrative workers and people working in specialist positions. In cluster No. 3 and cluster No. 4, most people worked in professional and administrative positions.

There is a statistically significant relationship between belonging to one of the four separate clusters and a respondent's period of employment, 2 (12) = $22.90, \mathrm{p}<0.05$. Table 10 shows the frequency distribution for the period of employment of the respondents according to their particular clusters. $\chi$ 
Table 10. Characteristics of separate clusters - the period of employment

\begin{tabular}{|c|c|c|c|c|c|c|c|c|}
\hline \multirow[b]{3}{*}{ Employment } & \multicolumn{8}{|c|}{ Cluster } \\
\hline & \multicolumn{2}{|c|}{ No. 1} & \multicolumn{2}{|c|}{ No. 2} & \multicolumn{2}{|c|}{ No. 3} & \multicolumn{2}{|c|}{ No. 4} \\
\hline & $n$ & $\%$ & $n$ & $\%$ & $n$ & $\%$ & $n$ & $\%$ \\
\hline less than a year & 1 & 5.6 & 11 & 24.4 & 26 & 36.1 & 17 & 28.8 \\
\hline $1-2$ years & 6 & 33.3 & 15 & 33.3 & 25 & 34.7 & 19 & 32.2 \\
\hline 3-5 years & 3 & 16.7 & 11 & 24.4 & 16 & 22.2 & 16 & 27.1 \\
\hline 5-10 years & 5 & 27.8 & 3 & 6.7 & 3 & 4.2 & 3 & 5.1 \\
\hline Over 10 years & 3 & 16.7 & 5 & 11.1 & 2 & 2.8 & 4 & 6.8 \\
\hline In total & 18 & 100.0 & 45 & 100.0 & 72 & 100.0 & 59 & 100.0 \\
\hline
\end{tabular}

Notes: $\mathrm{n}$ - number of persons; \% - the percentage of the group

Table 11. Characteristics of separate clusters - a form of employment

\begin{tabular}{lccccccccc}
\hline & \multicolumn{1}{c}{ Cluster } \\
\hline & \multicolumn{1}{c}{ No. 1 } & \multicolumn{1}{c}{ No. 2 } & \multicolumn{1}{c}{ No. 3 } & \multicolumn{2}{c}{ No. 4 } \\
\hline Employment & $\mathrm{n}$ & $\%$ & $\mathrm{n}$ & $\%$ & $\mathrm{n}$ & $\%$ & $\mathrm{n}$ & $\%$ \\
contract for indefinite duration & 14 & 77.8 & 21 & 50.0 & 28 & 41.8 & 27 & 48.2 \\
contract for a specified period & 1 & 5.6 & 13 & 31.0 & 18 & 26.9 & 21 & 37.5 \\
contract of mandate/specific work & 3 & 16.7 & 8 & 19.0 & 21 & 31.3 & 8 & 14.3 \\
In total & 18 & 100.0 & 42 & 100.0 & 67 & 100.0 & 56 & 100.0 \\
Over 10 years & 3 & 16.7 & 5 & 11.1 & 2 & 2.8 & 4 & 6.8 \\
In total & $\mathbf{1 8}$ & $\mathbf{1 0 0 . 0}$ & $\mathbf{4 5}$ & $\mathbf{1 0 0 . 0}$ & $\mathbf{7 2}$ & $\mathbf{1 0 0 . 0}$ & $\mathbf{5 9}$ & $\mathbf{1 0 0 . 0}$ \\
\hline
\end{tabular}

Notes: $\mathrm{n}$ - number of persons; \% - the percentage of the group

Among the people from cluster No. 1, there were a higher percentage of people with long work experience than in the other clusters, while in clusters No. 2, 3 and 4 most people had work experience of less than 5 years.

In addition, there was a statistically significant relationship between belonging to one of the four separate clusters and form of employment, 2 (6) = $13.33, \mathrm{p}<0.05$. Table 11 presents the frequency distribution for the form of employment of the respondents according to their particular clusters. $\chi$

Among the people from cluster 1, there was a higher percentage of people working under a contract of indefinite duration than in the other clusters. Generally, most of the respondents in all of the clusters were employed for an indefinite period of time.

In conclusion, we can say that the people tested in particular clusters and groups are characterized as follows:
Cluster / Group No. 1 - the people who assessed that the various factors have little effect on their job contentment. Generally in this group:

- there were more women than men.

- most people were aged 20-29, but at a lower percentage than in the other groups.

- there was highest percentage of workers that had been employed for over 5 years compared to the other clusters.

- there was the highest percentage of manual workers.

- there was a higher percentage of people working under a contract of indefinite duration than in the other groups.

Cluster / group 2 - the people who assessed that most of the factors have little impact on their job contentment. The exceptions were communication between the employees and other groups, good relationships with colleagues and working atmosphere. Generally in this group: 
- the number of men and women was similar.

- most people were aged 20-29.

- there was approximately the same number of manual and administrative workers as well as people working in specialist positions.

- most people in this group were employed for less than 5 years.

- most people worked under a contract of indefinite duration.

The third cluster / group of the respondents were formed by people who showed that all of the analyzed factors had a strong influence on their level of job contentment. The most important factors were communication with management, the recognition of superiors, good relations with superiors, good relationships with colleagues and working atmosphere. Generally in this group:

- there were more women than men.

most people were aged 20-29.

- most people worked in specialist and administrative positions.

- most people were employed for less than 5 years.

- most people worked under a contract of indefinite duration.

The fourth cluster / group were the people who evaluated that the most important factors for job contentment were job stability, opportunity for promotion, development opportunities and work content. Generally in this group:

- there were more women than men.

- most people were aged 20-29.

- most people worked in specialist and administrative positions.

- most people were employed for less than 5 years.

- most people worked under a contract of indefinite duration.

\section{Summary}

In the literature, job satisfaction is identified with a positive attitude to the work performed, to coworkers and the entire organization. We may also assume that a satisfied employee builds and participates in the success of any organization. According to experts, job satisfaction is considered in many categories. Listed, among others, are: economic aspects of work, interpersonal relationships, activities and tasks, and working conditions (Herzberg, 1965, pp. 364-376; Locke,
Smith, Kendall, Hulin \& Miller, 1964, pp.313-319; Zalewska, 2001, pp. 197-218). For each of these categories there are included a variety of factors that are then evaluated by the staff in terms of their satisfaction or dissatisfaction. Thus, the overall level of job satisfaction consist of many sub-factors. Many researchers, especially managers, wonder which individual factors have an impact on job satisfaction. Companies take action to identify these factors so that they can make workers work willingly for the benefit and success of the organization. Generally it can be said that satisfaction is seen as a multidimensional attitude.

The study, conducted and presented in this article, was to identify the factors affecting job satisfaction. It should be noted that the survey was completed by people who worked in different organizations and who were chosen in a random manner.

The analysis shows that in the opinions of 215 respondents, the factor with the greatest impact on job satisfaction was the atmosphere at work, and the factor with the least impact - the culture of the company. It turned out that by grouping factors and examining them in different categories, the most important factors are associated with interpersonal relations and economic aspects of work, but just comparing between factors, employment stability was rated as the most important. Thus, according to the respondents, the factor having the second greatest impact on job satisfaction is job stability.

The author of the study classified the following factors as those associated with interpersonal relations: good relations with colleagues, good relations with superiors, communication management, communication with other groups and the recognition of superiors. Surprising is the fact that the economic aspects of work, in addition to stability of employment, were indicated as having a lower impact on job satisfaction. One may wonder why, according to the respondents, the possibility of promotion or development has little impact on the overall assessment of job satisfaction. Perhaps the positive emotions that accompany interpersonal relationships play greater significance and satisfied people build positive relationships.

The individual factors that may include the following categories of activities and tasks in the evaluation of the respondents also have less impact on job satisfaction. Independence in decision making and con- 
tent of the work no longer play as significant a role as factors relating to interpersonal relationships. On the other hand, the category concerning working conditions, specified in the study as safety at work, has little but greater impact than the possibility of development or content of the work. This result is not surprising, because currently, employees pay attention to the environment in which they work but do not assign it much importance.

It is surprising that the least important factor affecting job satisfaction is company culture. It seems that this factor should play greater significance as it is the culture of the organization that sets the direction for the various benefits of a company and its prevailing rules.

An interesting research procedure was to divide the respondents into several groups. In this way, it was possible to learn which factors are specific to particular groups of respondents. It also allows you to specify how to all the respondents are characterized. Analyzing Figure 2, it can be seen that we have people who rated all the factors highly and for whom everything is important, those who begin to fluctuate in relation to certain factors and those who believe that the various factors have no impact on their job satisfaction. We have, therefore, people more or less involved in work. People more involved note that various factors play a greater significance in their level of job contentment.

Two groups (clusters) of the respondents (group 1 and 2) are generally dissatisfied with their work. In their opinions, the factors they were asked about in the survey have no effect on their overall job satisfaction. They valued these factors lower than others. The most dissatisfied group is the first one. Perhaps these are people who are professionally burnt out or who have lost their commitment to work and they only come to work because they have to.

What is, then, group 1? The majority are women, aged 20-29, employed in manual positions, employed for an indefinite period and have bigger experience. Another study conducted by the author on job satisfaction showed that it was blue collar workers who are the most dissatisfied with their work and that wages are the most important factor for their job satisfaction. Other factors no longer had great significance. The study also confirmed Herzberg's theory that depending on the work performed or position held, the weight attributed to factors influencing job contentment changes (Harris \& Locke, 1974, pp.. 369-370).

In addition, the respondents in group 1 indicated the factor with the least impact on their job satisfaction as the atmosphere at work and the factors with the biggest impacts as job stability, recognition of superiors and independence in decision making. However, it should be emphasized that the results of the assessment of individual factors are well below the average and are rated the lowest compared to the other groups.

Another group the results which are below the average, but higher than in the group 1, are those of group 2. The respondents of group 2 assessed that most of the factors have little impact on their job contentment. The exceptions are the communication between the employees and other groups, good relationships with colleagues and working atmosphere and the independence in decision-making.

Thus, who are the members of group 2? Well, they are similar in number of men and women, aged 2029 , about equally likely to be manual workers, administrative workers, or workers in specialist positions, employed on a permanent contract and have lengths of service of less than 5 years. In general, they are people dissatisfied with their work. In their opinion, the factors with the least impact on their job satisfaction are the recognition of superiors, work safety, good relations with superiors, company culture and the possibility of promotion. It seems that, similar to the people in group 1, they are people who are isolated, little involved in their work and professionally burnt out. As the supreme factor influencing job satisfaction, respondents indicated communication between employees and maintaining good relationships with colleagues. This may also be an aspect of compensating their unwillingness to work. Perhaps focusing on interpersonal relationships gives the people in group 2 a separate channel where their negative emotions have an outlet. It is also not surprising that the atmosphere at work has a big impact on their job satisfaction. Thus, people of group 2 are mainly focused on interpersonal relationships and have a low involvement in their jobs and their dissatisfaction compensated by building relationships with colleagues and the atmosphere at work.

The group that indicated more factors as having a positive impact on job satisfaction than the average is group 4 . Based on the analyses, this group 
consists mostly of women, people aged 20-29, workers in specialist and administrative positions, employees who have work experience for less than 5 years and workers who are employed under a contract of indefinite duration.

People in group 4 assessed that the factors with the highest importance for job contentment were job stability, opportunity for promotion, development opportunities and work content while factors with the lowest importance were communication between the employees and other groups, good relationships with colleagues and working atmosphere. As seen, this is in complete contrast to group 2, for which the most important factors are those classified under interpersonal relationships. For group four, the most important factors are included in the category of economic aspects of the business and partly included in the categories of activities and tasks, i.e., content of work, stability of employment, development and promotion opportunities. Other factors were rated above average but lower than those previously mentioned.

The last group of the respondents is group 3 . These are the people who value all the factors affecting job satisfaction above average. So who are these people? They are mostly women, aged 20-29, working in specialist and administrative positions, have been employed for less than 5 years and are employed under a contract of indefinite duration. Analyzing the above characteristics, it is not difficult to see that this group has the same profile as the respondents in group 4.

Generally people in group 3 showed that all of the analyzed factors have a strong influence on their job satisfaction. The most important factors were communication with the management, the recognition of superiors, good relations with superiors, good relationships with colleagues and working atmosphere.

Slightly less valued in group 3 , but still above average, were communication between employees and other groups, corporate culture and safety at work. The factors that were rated the lowest were stability of employment, job content and autonomy in decision making. In contrast, the possibility of promotion and development was evaluated similarly as the respondents of group 4, but less noticeable is their evaluation compared to the group 4. Group 4 was characterized by valuing the content their work as the factor with the highest impact on job satisfaction while there was a steep decline in the value of this factor in group 3.

It is not hard to see that in the general characteristics of the staff profiles, groups 3 and 4 do not differ from each other in terms of gender, age, length of service, length of employment and type of employment contract. So, what are the differences between group 3 and 4 ? It seems that the groups focus on different categories of factors affecting job satisfaction. Group 4 was focused on the factors of economic categories and aspects of activities and tasks, while group 3 focused mainly on factors in the category of interpersonal relationships. It can therefore be concluded that the internal control unit theme plays a huge role. People may have the same staff profile but will differ in terms of the impact of various factors on job contentment. For some, the priority is to satisfy the first need of belonging and interpersonal relationships in the workplace while for others, the most important themes are related to the economic aspects of the work, its content and the possibility of development and promotion. For the latter group of people, interpersonal relationships or working atmosphere does not play a significant role in job contentment.

The aim of the study was to identify and assess the significance of individual factors influencing satisfaction and dissatisfaction with work and demonstrate their impact on the overall assessment of job satisfaction. The study showed that between the weight attributed to individual factors and overall job satisfaction, there are many statistically significant correlations referring mainly to selected on the basis of analysis respondents' groups.

In the overall assessment of all 215 respondents, the atmosphere of work, job stability, good relations with colleagues and superiors are identified as factors that are of paramount importance. However, when analyzing these factors when respondents are distributed across clusters / groups we do not obtain the same results.

The study allows us to confirm the thesis in question concerning the validity of research on factors affecting job satisfaction. Undoubtedly, it is important to be able to determine how to keep good employees, how to increase their satisfaction and motivation to work and what to do to increase their commitment, devotion and loyalty. Thus, managers should be aware of the importance of job satisfaction of their employees as a determinant of building the right relationships 
thus increasing the performance of both the individual and the overall organization (Holland, Pyman, Cooper \& Teicher, 2011, pp. 95-111). Thanks to many previously conducted studies, companies recognize the importance of this issue. A satisfied employee builds and participates in the success of any organization.

\section{Bibliography}

Ariani, D. W. (2012). Leader-Member Exchanges as a Mediator of the Effect of Job Satisfaction on Affective Organizational Commitment: An Empirical Test. International Journal of Management, 29 (1), 46-56.

Armstrong, M. (2000). Zarzadzanie Zasobami Ludzkimi [Human Resource Management]. Cracow: Oficyna Ekonomiczna.

Armstrong, M. (2004). Zarządzanie Zasobami Ludzkimi [Human Resource Management]. Cracow: Oficyna Ekonomiczna.

Armstrong, M. (2005). Zarzadzanie Zasobami Ludzkimi [Human Resource Management. Cracow]: Oficyna Ekonomiczna.

Argyle, M. (2004). Psychologia szczęścia [Psychology of happiness]. Wrocław: Astrum.

Bańka, A. (2002). Psychologia organizacji [Psychology of the organization]. In J. Strelau (Ed.), Psychologia. Podręcznik Akademicki [Psychology. Academic Handbook]. (Vol. 3) (pp. 321-350). Gdańsk: GWP.

Bojewska, B. (2006). Zależności pomiędzy kulturą organizacyjną a strategią personalną przedsiębiorstwa [Relationships between organizational culture and strategy of the company personnel]. In H. Król (ed.), Ewolucja zarządzania organizacjami na przełomie wieków [The evolution of management organizations at the turn of the century]. (pp. 481-495). Warszawa: Vizja Press.

Brief, A. P., Weiss, H. M. (2002). Organizational behavior: Affect in the work-place. Annual Review of Psychology, 53, 279-307.

Fein, M. (1970). Approaches to Motivation, Hillsdale, NJ: Hillsdale Press.

Furnham, A. (2008). Personalisty and intelligence at work. Exploring and explaining individual differences at work. New York: Routledge.
Griffin, R. (1998). Podstawy zarządzania organizacja$m i$ [Basics of managing organizations]. Warszawa: PWN.

Harris, T. C., Locke, E. A. (1974). Replication of whitecollar-blue-collar differences in sources of satisfaction and dissatisfaction. Journal of Applied Psychology, 59 (3), 369-370.

Herzberg, F. (1965). The new industrial psychology. Industrial and Labor Relations Review, 18 (3), 364-376.

Hoffman, E. (2003). Ocena psychologiczna pracowników [Psychological evaluation of employees]. Gdańsk: GWP.

Holland, P., Pyman, A., Cooper, B. K., \& Teicher, J. (2011). Employee Voice and Job Satisfaction In Australia: The Centrality of Direct Coice. Human Resource Management, 50 (1), 95-111.

Isen, A. (2005). Pozytywny afekt i podejmowanie decyzji [Positive affect and decision making]. In M. Lewis, J. M. Haviland-Jones (Eds.), Psychologia emocji [Psychology of emotions]. (pp. 527-549). Gdańsk: GWP.

Jachnis, A. (2008). Psychologia organizacji: kluczowe zagadnienia [Psychology of organizations: key issues]. Warszawa: Difin.

Jorfi, H., Fauzy Bin Yacco, H., Md Ishah, I. (2012). Role of Gender In Emotional Intelligence: Relationship among Emotional Intelligence, Communication Effectiveness and Job Satisfaction. International Journal of Management, 29 (4), 590-597.

Locke, E. A., Smith, P. C., Kendall, L. M., Hulin, C. L., Miller, A. M. (1964). Convergent and discriminant validity for areas and methods of rating job satisfaction. Journal of Applied Psychology, 48 (5), 313-319.

Maslach, C. (2000). Wypalenie w perspektywie wielowymiarowej [Burnout - a multidimensional perspective]. In H. Sęk (Ed.), Wypalenie zawodowe nauczycieli. Przyczyny mechanizmy zapobieganie [Professional burnout. The causes, mechanisms, prevention] (pp. 13-31). Warszawa: PWN.

Mrzygłód, J. (2004). Badanie satysfakcji pracowników [Employee satisfaction survey]. In T. Rostkowski (Ed.), Nowoczesne zarządzanie zasobami ludzkimi [Modern human resources management] (pp. 183-196). Warszawa: Difin.

Ogińska-Bulik, N. (2006). Stres zawodowy w zawodach ustug społecznych [Professional stress in social services occupations: sources, consequences, prevention]. Warszawa: Difin. 
Pocztowski, A. (2003). Zarządzanie zasobami ludzkimi [Human Resource Management]. Warszawa: PWE. Makin, P., Cooper, G., Cox, C. (2000). Organizacje a kontrakt psychologiczny. Zarządzanie ludźmi $w$ organizacji [Organizations and the psychological contract. Managing people in the organization]. Warszawa: PWN.

Pratt, M. G., Ashforth, B. E. (2003). Fostering meaningfulness in working and at work. In K. S. Cameron, J. E. Dutton, R. E. Quinn (Eds.), Positive organizational scholarship: foundations of a new discipline, (pp. 309-327). San Francisco, CA: Berrett-Koehlers.

Rogelberg, S. G., Allen, J. A., Shanock, L., Scott, C. W., Shuffler, M. (2010). Employee Satisfaction with meetings: A contemporary Facet of Job satisfaction, Human Resource Management, 49 (2), 149-172.

Sarmiento, T. P., Laschinger, H. K., Iwasiw, C. (2004). Nurse educators' work-place empowerment, burnout, and job satisfaction: Testing Kanter's theory. Journal of Advanced Nursing, 46 (2), 134-143.

Sęk, H. (2000). Wypalenie zawodowe u nauczycieli: uwarunkowania i możliwości zapobiegania [Burnout of teachers: Conditions and possibilities for prevention]. In H. Sęk (Ed.), Wypalenie zawodowe nauczycieli. Przyczyny mechanizmy zapobieganie [Professional burnout. The causes, mechanisms, prevention] (pp. 149-167). Warszawa: PWN.

Stride, C., Wall, T. D., Catley, N. (2007). Measures of job satisfactions, organizational commitment, mental health and job-related well-being: A bench-marking manual (2nd ed.). West Sussex, UK: John Wiley and Sons.

Wang, Y., Yang, C., Wang, K. (2012). Comparing Public and Private Employees' Job Satisfaction and Turnover. Public Personnel Management, 41 (3), 557-573.

Zalewska, A. (2001). "Sheet of job description" O. Neuberger and M. Allerbeck-adaptation to Polish conditions. Psychological Studies, 39 (1), 197-218.

Zalewska, A. (2003). Dwa światy. Emocjonalne i poznawcze oceny jakości życia $i$ ich uwarunkowania u osób o wysokiej i niskiej reaktywności [Two worlds. Emotional and cognitive assessment of quality of life and their causes in subjects with high and low reactivity]. Warsaw: Wydawnictwo SWPS. 
